\title{
Correction to: EFL teachers' perceptions and practices of their language assessment knowledge
}

\author{
Hossein Farhady ${ }^{1}$ and Kobra Tavassoli $i^{2^{*}}$
}

\author{
The original article can be found \\ online at https://doi.org/10.1186/ \\ s40468-021-00135-4. \\ * Correspondence: kobra.tavassoli@ \\ kiau.ac.ir \\ ${ }^{2}$ Department of ELT, Karaj Branch, \\ Islamic Azad University, Karaj, Iran \\ Full list of author information is \\ available at the end of the article
}

\section{Correction to: Lang Test Asia 11, 17 (2021) \\ https://doi.org/10.1186/s40468-021-00135-4}

Following publication of this article (Farhady \& Tavassoli, 2021), it is reported that the below changes need to be made.

1. The sentence below need to be removed from 'Review of the related literature' section on page 3.

'American Federation of Teachers, National Council on Measurement in Education' The correct sentence should read:

As early as the 1990s, the American Federation of Teachers, the National Council on Measurement in Education, and the National Education Association (AFT, NCME, \& NEA, 1990) developed some guidelines and standards to help teacher educators and teachers recognize the significance of LAK in and out of classroom context.

2. The citation 'Farhady \& Tavassoli, 2018a' on page 8 and page 15 should be changed to 'Farhady \& Tavassoli, 2018'.

The original article has been updated.

\section{Author details}

'ELT Department, Yeditepe University, İnönü Mah. Kayışdağı Cad., 26 Ağustos Yerleşimi, 34755 Ataşehir, Istanbul, Turkey. ${ }^{2}$ Department of ELT, Karaj Branch, Islamic Azad University, Karaj, Iran.

Published online: 15 November 2021

\section{Reference}

Farhady, H., \& Tavassoli, K. (2021). EFL teachers' perceptions and practices of their language assessment knowledge. Language Testing in Asia, 11, 17 https://doi.org/10.1186/540468-021-00135-4.

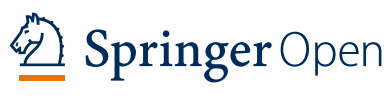

๑ The Author(s). 2021 Open Access This article is licensed under a Creative Commons Attribution 4.0 International License, which permits use, sharing, adaptation, distribution and reproduction in any medium or format, as long as you give appropriate credit to the original author(s) and the source, provide a link to the Creative Commons licence, and indicate if changes were made. The images or other third party material in this article are included in the article's Creative Commons licence, unless indicated otherwise in a credit line to the material. If material is not included in the article's Creative Commons licence and your intended use is not permitted by statutory regulation or exceeds the permitted use, you will need to obtain permission directly from the copyright holder. To view a copy of this licence, visit http://creativecommons.org/licenses/by/4.0/. 